\title{
Use of radiotelemetry to track threatened dorados Salminus brasiliensis in the upper Uruguay River, Brazil
}

\author{
Lisiane Hahn ${ }^{1, *}$, Angelo A. Agostinho ${ }^{2}$, Karl K. English ${ }^{3}$, Joachim Carosfeld ${ }^{4}$, \\ Luís Fernando da Câmara ${ }^{1}$, Steven J. Cooke ${ }^{5}$ \\ ${ }^{1}$ Neotropical Environmental Consulting Company, Passo Fundo, Rio Grande do Sul 99074-210, Brazil \\ ${ }^{2}$ Maringá State University, Maringá, Paraná 87020-900, Brazil \\ ${ }^{3}$ LGL Limited - Environmental Research Associates, Sidney, British Columbia V8L 3Y8, Canada \\ ${ }^{4}$ WFT - World Fisheries Trust, Victoria, British Columbia V9A 3X3, Canada \\ ${ }^{5}$ Fish Ecology and Conservation Physiology Lab, Carleton University, Ottawa, Ontario K1S 5B6, Canada
}

\begin{abstract}
Little is known about the seasonal movements of fish that inhabit large rivers in South America, which makes it difficult to identify potential threats to fish populations associated with the proliferation of hydropower developments. Dorados Salminus brasiliensis (Characiformes) are large riverine piscivores that are targeted by recreational and commercial fishers and are considered regionally 'vulnerable' in Brazil due to overfishing, pollution, and habitat fragmentation. Here, we used radio telemetry to study the seasonal movements of dorados in the upper Uruguay River, Brazil, to provide the first information on large-scale migratory biology and to inform management and conservation actions. From November 2001 to July 2003, 73 dorados were radio-tracked using aerial surveys and 7 fixed radio telemetry stations installed in a section of the upper Uruguay River covering $\sim 400 \mathrm{~km}$. Despite use of an extensive radio telemetry array and aerial tracking, nearly $40 \%$ of fish tagged at the downstream site were never detected, suggesting unreported harvest, post-release mortality, or migration to tributaries or downstream reaches that extended beyond the tracking area, emphasizing the challenges of working in such a large study system in jurisdictions where research capacity and funding are limited. Nonetheless, this study yielded the first data on the migratory biology of dorados and revealed that a segment of the population is quite mobile and thus could be negatively impacted by river fragmentation, suggesting the need for management strategies that maintain connectivity (e.g. fish passage facilities).
\end{abstract}

KEY WORDS: Salminus brasiliensis · Migration · Upper Uruguay River · Radio telemetry · Itá Dam · Turvo Forest Park

Resale or republication not permitted without written consent of the publisher

\section{INTRODUCTION}

There is a lack of research on the natural history and behavior of fish in large tropical rivers (Wishart et al. 2000). This is of particular concern because of the many threats that face fish residing in large tropical rivers such as overfishing, pollution, forestry, agriculture, and hydropower development (Pringle
2000, Malmqvist \& Rundle 2002). Given that migratory fish occupy large areas in the river basin, they have the potential to be exposed to multiple threats; thus, there is a need to document and describe the migratory biology of fish residing in large tropical rivers. Although a number of tools are available for studying fish movement in large rivers (reviewed by Lucas \& Baras 2000), biotelemetry techniques such as 
radio and acoustic telemetry perhaps hold the greatest potential, given the possibility for fish to undertake vast migrations in such watersheds. A recent synthesis revealed that biotelemetry tools have much to offer in the study of threatened fish species as such tools make it possible to document critical habitats and identify the level of riverine connectivity required for the species' life history (Cooke 2008). To date, only a handful of telemetry studies have been conducted in large tropical rivers (Hocutt et al. 1994, Thorstad et al. 2001), despite the fact that such tools have been widely used in temperate rivers since the 1970s (Baras 1991).

One region that is particularly poorly studied with respect to migratory fish is South America (Wishart et al. 2000, Carosfeld \& Harvey 2003). The upper Paraná River basin in Brazil is considered one of the most studied with respect to fish fauna in South America, but even there, information on the basic natural history is known for only 86 of the 221 currently identified fish species (Agostinho et al. 2003). The lack of information on natural history and migratory biology of species makes it difficult to conduct threat assessments and to develop management strategies to address challenges such as hydropower development and overfishing. Throughout South America, but in particular in Brazil, large-scale hydropower developments have taken place (130 dams higher than $10 \mathrm{~m}$ in the Paraná River Basin alone, as of 2001; Agostinho et al. 2002) and many more are planned. Regulations do not require fish passage facilities in Brazil to be constructed unless a need is demonstrated, so a lack of information on migratory tendencies makes it difficult for environmental managers to make decisions regarding fish passage needs (see Agostinho et al. 2002 for details). In many other regions of the world, however, maintenance of river connectivity for fish populations is regarded as critical, particularly for migratory species (Malmqvist \& Rundle 2002, Nilsson et al. 2005).

The dorado Salminus brasiliensis Cuvier, 1816 is the largest characin in the La Plata River Basin, growing to $116 \mathrm{~cm}$ and $31.6 \mathrm{~kg}$ (Morais-Filho \& Schubart 1955), and has a wide distribution in South America (Lowe-McConnell 1975). This species is targeted by both sport and subsistence fisheries because of its excellent taste and ease of capture (Hahn 2000). Adult dorados are top piscivores in the aquatic food chain, and they tend to feed in fastrunning waters primarily during the twilight period. Previous mark-recapture studies have revealed that dorados appear to exhibit seasonal migrations between feeding and spawning areas, covering dis- tances up to $1000 \mathrm{~km}$ (Petrere 1985). However, mark-recapture studies have serious limitations, and there is a tendency to underestimate the mobility of the population (Lucas \& Baras 2000). The spawning migration of dorados in the Paraná River Basin is related to the flood regime of a particular year (Agostinho et al. 2003), with most dorados initiating spawning activity after the water levels have begun to rise (Godoy 1975). The destruction of habitat, interruption of the migratory routes by dams, and especially over-fishing have caused this species to be considered vulnerable according to the red list of endangered species for the state of Rio Grande do Sul (Marques et al. 2002). Documenting the migratory biology of dorados in the upper Uruguay River basin of Brazil using biotelemetry would address a critical information gap and provide managers with knowledge needed to make informed management and conservation decisions.

The objective of this study was to document and describe the movement patterns and migratory tendencies of dorados in the upper Uruguay River. Research efforts focused in a reach approximately $400 \mathrm{~km}$ in length and involved radio tagging fish at the upstream extent of the study reach where there was an impassable dam, as well as some $325 \mathrm{~km}$ downstream near the lower portion of the study reach. Such a tagging design enabled us to further explore whether fish tagged in 2 locations exhibited different movement patterns. Aerial tracking and fixed radio receiver stations were used over a $3 \mathrm{yr}$ period, enabling us to also evaluate seasonal patterns in movement. Given that this is one of the first radio telemetry studies of migratory fish in South America or any Neotropical river, we also discuss the challenges involved in using such technology in a region where research capacity and funding are limited and where the watersheds are massive. We also discuss how our findings could inform management and conservation initiatives, particularly those related to mitigating fragmentation effects associated with hydropower development.

\section{MATERIALS AND METHODS}

\section{Study area}

The Uruguay River, the third largest in the La Plata River basin, is $1838 \mathrm{~km}$ long and covers a drainage area of greater than $365000 \mathrm{~km}^{2}$ (OEA 1969). Its headwaters are in the Serra do Mar and Serra Geral, the coastal ranges of southern Brazil. Its main source, 
the Pelotas River, originates only $64 \mathrm{~km}$ from the Atlantic coast and flows to meet the Canoas River at $1800 \mathrm{~m}$ above sea level, thus giving rise to the mainstream of the Uruguay River. In Buenos Aires, it combines with the Paraná River, forming the great estuary of the La Plata River (Di Persia \& Neiff 1986).

The upper Uruguay River has a great diversity of habitats; extensive series of riffle and rapid sections are predominant because of the rocky substrate and high gradient. However, deep pools and sand beds are common in some stretches. The mean river width is $400 \mathrm{~m}$ (max. $1300 \mathrm{~m}$ ) with depths of up to $130 \mathrm{~m}$ at a site in Yucumã Falls, Turvo Forest Park, in a border area between Brazil and Argentina. The water temperature varies seasonally from 10 to $28^{\circ} \mathrm{C}$, conductivity from 30 to $100 \mu \mathrm{S} \mathrm{cm}^{-1}$, and pH from 6 to 8 .

The Uruguay River basin has suffered a variety of negative impacts since the beginning of the last century. Nearly all of the riparian vegetation had been removed by the 1950s when 'balsas' (boats) were used to transport wood harvested from the margins of the river downstream to Argentina (Pesavento 1982). At present, the only intact sections of original riparian vegetation are located in the Turvo Forest Park (Brazil) and Missiones Forest (Argentina), which together cover $50 \mathrm{~km}$ of the river (Hahn \& Câmara 2000).
The study area is a stretch of the upper Uruguay River about $400 \mathrm{~km}$ long (between 1050 and $1450 \mathrm{~km}$ from the river mouth; Fig. 1). The upstream limit of the study area is the Itá Dam, which began operation in December 2000. The dam is $125 \mathrm{~m}$ in height and is not equipped with fish passage facilities, so it is presumably a barrier to fish migration. The downstream limit of the study site was the city of Porto Soberbo, downstream of the Turvo Forest Park and Missiones Forest.

\section{Fish sampling and tagging}

From November 2001 to July 2003, 73 dorados were captured at 2 collection sites in the study area (Table 1). Forty-two were captured along the Yucumã falls, Turvo Forest Park (Site A) and 31 in the tailrace of Itá Dam (Site B). The specific collection sites were chosen because these areas had been identified by researchers as areas where fish capture would be possible due to an apparent concentration of fish. The purpose of tagging fish from an upstream and downstream site separated by 325 river $\mathrm{km}$ was to test whether there was overlap in use of different reaches of the river. In addition, because Itá Dam is a migratory barrier with no appropriate spawning

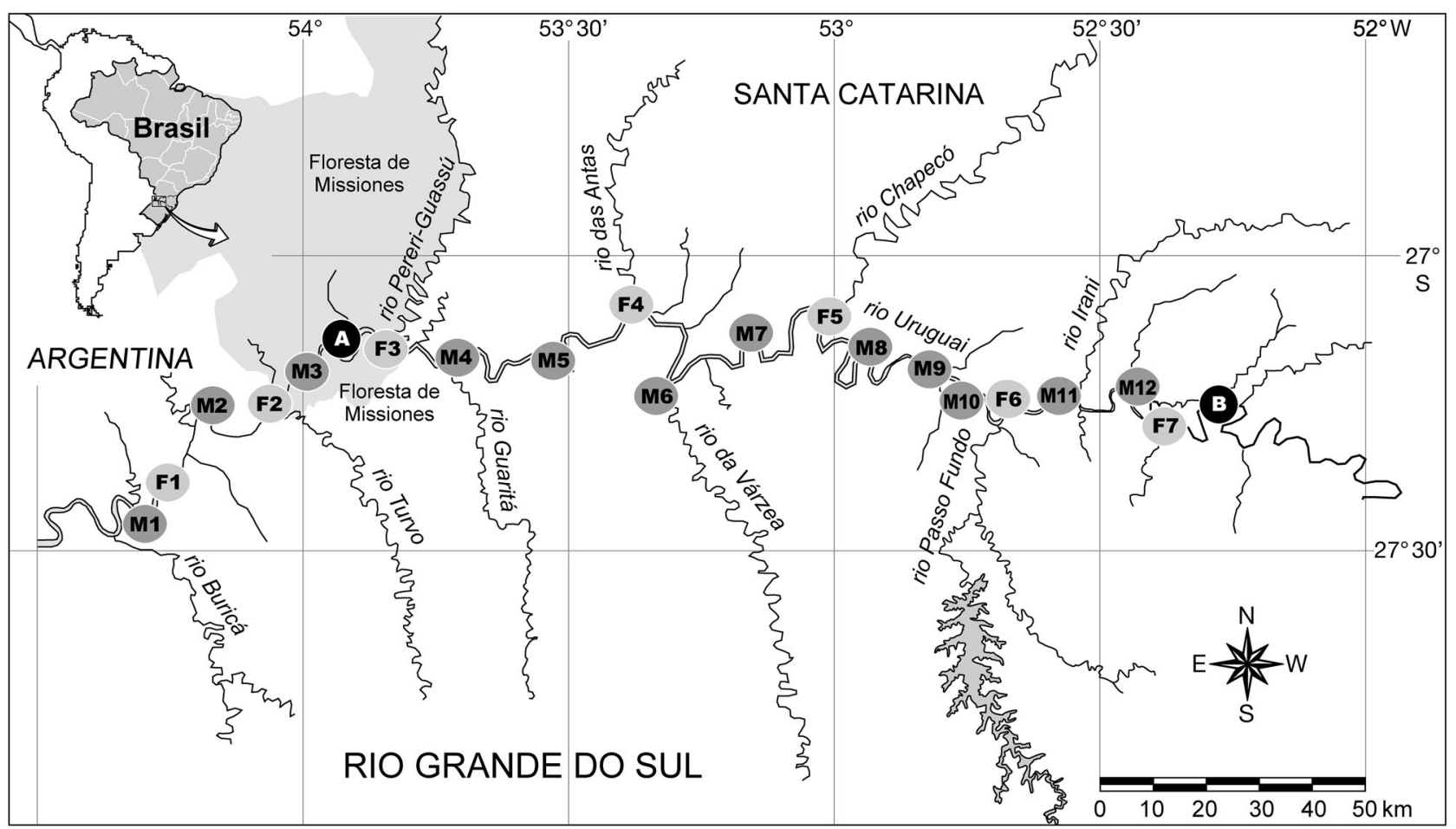

Fig. 1. Study area in the upper Uruguay River, Brazil. A: release site in the Turvo Forest Park, B: release site in the tailrace (downstream) of the Itá Dam. Radio telemetry fixed stations: F1 to F7. Mobile tracking zones: M1 to M12 
Table 1. Salminus brasiliensis. Dorados radio-tagged from November 2001 to July 2003. M: male; F: female; nd: not determined. Release sites: A, Turvo Forest Park; B, Itá Dam (see Fig. 1)

\begin{tabular}{|c|c|c|c|c|c|c|c|c|}
\hline $\begin{array}{l}\text { Fish } \\
\text { no. }\end{array}$ & $\begin{array}{l}\text { Tagging date } \\
\text { (mm/dd/yy) }\end{array}$ & Sex & $\begin{array}{c}\text { Total } \\
\text { length }(\mathrm{cm})\end{array}$ & $\begin{array}{c}\text { Total } \\
\text { weight }(\mathrm{kg})\end{array}$ & $\begin{array}{l}\text { Tagging } \\
\text { site }\end{array}$ & $\begin{array}{c}\text { No. of } \\
\text { detections }\end{array}$ & $\begin{array}{l}\text { Total time } \\
\text { tracked }(\mathrm{d})\end{array}$ & Comments \\
\hline 1 & 11/28/01 & nd & 80 & 8.5 & $\mathrm{~A}$ & 51 & 825 & \\
\hline 2 & $11 / 29 / 01$ & nd & 64 & 2.5 & $\mathrm{~A}$ & 38 & 837 & \\
\hline 3 & $11 / 29 / 01$ & nd & 72 & 2.85 & A & 183 & 845 & \\
\hline 4 & $12 / 13 / 01$ & $\mathrm{~F}$ & 92 & 9.5 & $\mathrm{~A}$ & 8 & 85 & \\
\hline 5 & $12 / 13 / 01$ & $\mathrm{~F}$ & 88 & 7.5 & A & 18 & 52 & \\
\hline 6 & $12 / 13 / 01$ & $\mathrm{M}$ & 60.5 & 2.7 & A & 3 & 296 & \\
\hline 7 & $12 / 13 / 01$ & M & 61 & 2.6 & $\mathrm{~A}$ & 3 & 737 & \\
\hline 8 & $01 / 16 / 02$ & M & 67 & 3.0 & $\mathrm{~A}$ & 26 & 36 & \\
\hline 9 & $01 / 25 / 02$ & $\mathrm{M}$ & 53 & 1.4 & $\mathrm{~A}$ & 0 & 0 & \\
\hline 10 & $03 / 12 / 02$ & $\mathrm{~F}$ & 73 & 4.5 & $\mathrm{~A}$ & 0 & 0 & \\
\hline 11 & $03 / 12 / 02$ & $\mathrm{~F}$ & 83 & 7.5 & $\mathrm{~A}$ & 1 & 222 & \\
\hline 12 & $03 / 12 / 02$ & $\mathrm{~F}$ & 72 & 4.5 & $\mathrm{~A}$ & 0 & 0 & \\
\hline 13 & $03 / 12 / 02$ & $\mathrm{~F}$ & 75 & 4.8 & $\mathrm{~A}$ & 9 & 649 & \\
\hline 14 & 03/13/02 & $\mathrm{F}$ & 68 & 3.5 & $\mathrm{~A}$ & 0 & 0 & \\
\hline 15 & 03/13/02 & $\mathrm{F}$ & 68 & 3.0 & $\mathrm{~A}$ & 3 & 409 & \\
\hline 16 & 03/14/02 & $\mathrm{F}$ & 69 & 3.5 & $\mathrm{~A}$ & 16113 & 48 & \\
\hline 17 & 03/14/02 & $\mathrm{F}$ & 62 & 2.8 & A & 0 & 0 & \\
\hline 18 & $11 / 29 / 01$ & nd & 34 & 0.65 & A & 1 & 99 & $\begin{array}{l}\text { Captured. Location and time } \\
\text { were not reported by fisher }\end{array}$ \\
\hline 19 & 12/13/01 & M & 57 & 2.2 & $\mathrm{~A}$ & 1 & 27 & \\
\hline 20 & 01/16/02 & M & 60 & 1.9 & A & 0 & 0 & $\begin{array}{l}\text { Captured in April 2004, } 300 \mathrm{~km} \\
\text { downstream of the release site }\end{array}$ \\
\hline 21 & 04/08/02 & $\mathrm{F}$ & 85 & 6.0 & $\mathrm{~A}$ & 0 & 0 & \\
\hline 22 & $04 / 08 / 02$ & $\mathrm{~F}$ & 75 & 4.5 & $\mathrm{~A}$ & 2 & 560 & \\
\hline 23 & $04 / 08 / 02$ & $\mathrm{~F}$ & 97 & 11.0 & A & 1 & 560 & \\
\hline 24 & 04/10/02 & $\mathrm{F}$ & 67 & 2.5 & A & 0 & 0 & \\
\hline 25 & 04/10/02 & $\mathrm{F}$ & 79.5 & 6.0 & $\mathrm{~A}$ & 0 & 0 & \\
\hline 26 & 04/10/02 & nd & 74 & 4.1 & $\mathrm{~A}$ & 1 & 216 & \\
\hline 27 & $04 / 10 / 02$ & $\mathrm{~F}$ & 85 & 7.5 & A & 0 & 0 & \\
\hline 28 & $04 / 10 / 02$ & $\mathrm{~F}$ & 90 & 8.0 & A & 7 & 714 & \\
\hline 29 & $04 / 11 / 02$ & $\mathrm{~F}$ & 83 & 7.0 & A & 2 & 237 & \\
\hline 30 & $04 / 11 / 02$ & $\mathrm{~F}$ & 64 & 3.5 & A & 0 & 0 & \\
\hline 31 & $04 / 11 / 02$ & $\mathrm{~F}$ & 97 & 11.0 & $\mathrm{~A}$ & 3 & 382 & \\
\hline 32 & $04 / 11 / 02$ & $\mathrm{~F}$ & 85 & 9.0 & $\mathrm{~A}$ & 130 & 704 & \\
\hline 33 & $04 / 11 / 02$ & $\mathrm{~F}$ & 70 & 3.5 & A & 0 & 0 & \\
\hline 34 & $04 / 11 / 02$ & $\mathrm{~F}$ & 79 & 6.5 & A & 0 & 0 & \\
\hline 35 & $04 / 11 / 02$ & $\mathrm{~F}$ & 81.5 & 6.0 & A & 5 & 675 & \\
\hline 36 & $04 / 30 / 02$ & nd & 67 & 4.6 & $\mathrm{~A}$ & 1 & 578 & \\
\hline 37 & $01 / 18 / 02$ & nd & 34.5 & 0.3 & A & 4 & 769 & $\begin{array}{l}\text { Captured. Location and time } \\
\text { were not reported by fisher }\end{array}$ \\
\hline 38 & $01 / 25 / 02$ & M & 49 & 1.0 & $\mathrm{~A}$ & 0 & 0 & \\
\hline 39 & $12 / 13 / 01$ & $\mathrm{~F}$ & 59 & 2.2 & $\mathrm{~A}$ & 0 & 0 & \\
\hline 40 & $11 / 26 / 01$ & $\mathrm{M}$ & 65 & 3.5 & A & 1 & 138 & \\
\hline 41 & $11 / 29 / 01$ & nd & 63 & 2.5 & A & 0 & 0 & \\
\hline 42 & $11 / 29 / 01$ & nd & 62 & 2.0 & $\mathrm{~A}$ & 0 & 0 & \\
\hline 43 & $12 / 11 / 01$ & $\mathrm{~F}$ & 78 & 6.0 & B & 6 & 828 & $\begin{array}{l}\text { Captured in February } 2002, \\
50 \mathrm{~km} \text { downstream of the } \\
\text { release site }\end{array}$ \\
\hline 44 & $12 / 11 / 01$ & $\mathrm{~F}$ & 65 & 4.3 & B & 8 & 270 & \\
\hline 45 & $01 / 09 / 02$ & $\mathrm{~F}$ & 70 & 5.0 & B & 8716 & 781 & \\
\hline 46 & $01 / 10 / 02$ & $\mathrm{~F}$ & 66 & 3.7 & B & 4831 & 66 & \\
\hline 47 & $01 / 10 / 02$ & $\mathrm{~F}$ & 80 & 9.0 & B & 5934 & 55 & $\begin{array}{l}\text { Captured in March 2002, } 81 \mathrm{~km} \\
\text { downstream of the release site }\end{array}$ \\
\hline 48 & 01/10/02 & $\mathrm{F}$ & 68 & 4.75 & B & 8586 & 764 & $\begin{array}{l}\text { Captured in October } 2002 \text { on a } \\
\text { tributary } 1 \mathrm{~km} \text { downstream } \\
\text { from the release site }\end{array}$ \\
\hline 49 & 01/11/02 & $\mathrm{F}$ & 64 & 3.9 & B & 4687 & 802 & \\
\hline 50 & $01 / 11 / 02$ & $\mathrm{~F}$ & 78 & 5.8 & B & 14359 & 239 & \\
\hline
\end{tabular}


Table 1 (continued)

\begin{tabular}{|c|c|c|c|c|c|c|c|c|}
\hline 51 & $01 / 11 / 02$ & $\mathrm{~F}$ & 78 & 8.3 & B & 4348 & 377 & \\
\hline 52 & 01/11/02 & $\mathrm{F}$ & 68 & 4.9 & B & 238 & 804 & \\
\hline 53 & $01 / 11 / 02$ & $\mathrm{~F}$ & 68 & 4.9 & B & 1756 & 239 & \\
\hline 54 & $01 / 11 / 02$ & M & 63 & 3.0 & B & 10556 & 780 & \\
\hline 55 & $03 / 27 / 02$ & $\mathrm{~F}$ & 73 & 5.2 & B & 130365 & 715 & \\
\hline 56 & $03 / 27 / 02$ & F & 74 & 5.2 & B & 1 & 189 & \\
\hline 57 & 03/28/02 & F & 63 & 3.3 & B & 1098 & 478 & $\begin{array}{l}\text { Captured in September } 2002 \text { at } \\
\text { the release site }\end{array}$ \\
\hline 58 & 03/28/02 & M & 68 & 3.4 & B & 15274 & 166 & $\begin{array}{l}\text { Captured. Location and time } \\
\text { were not reported by fisher }\end{array}$ \\
\hline 59 & 03/28/02 & F & 70 & 4.5 & B & 34946 & 726 & \\
\hline 60 & $12 / 12 / 01$ & F & 67 & 4.2 & B & 363 & 832 & \\
\hline 61 & 03/28/02 & F & 75 & 6.2 & B & 1046 & 700 & $\begin{array}{l}\text { Captured. Location and time } \\
\text { were not reported by fisher }\end{array}$ \\
\hline 62 & 05/14/03 & nd & 67 & 4.0 & B & 519 & 295 & $\begin{array}{l}\text { Captured in April } 2004 \text { at the } \\
\text { release site. Weight at capture: } \\
7.5 \mathrm{~kg}\end{array}$ \\
\hline 63 & 05/13/03 & F & 68 & 3.8 & B & 3 & 35 & \\
\hline 64 & 05/13/03 & $\mathrm{F}$ & 70 & 4.8 & B & 7153 & 312 & \\
\hline 65 & $12 / 19 / 02$ & M & 76 & 7.5 & B & 260 & 437 & \\
\hline 66 & $12 / 19 / 02$ & $\mathrm{~F}$ & 78 & 8.0 & B & 3 & 436 & \\
\hline 67 & $12 / 19 / 02$ & F & 73 & 6.5 & B & 1 & 11 & \\
\hline 68 & $05 / 13 / 03$ & F & 74 & 5.8 & B & 193 & 268 & $\begin{array}{l}\text { Captured in May 2004, } 128 \mathrm{~km} \\
\text { downstream of the release site. } \\
\text { Weight at capture: } 6.5 \mathrm{~kg}\end{array}$ \\
\hline 69 & $05 / 13 / 03$ & $\mathrm{~F}$ & 70 & 4.6 & B & 2213 & 318 & \\
\hline 70 & 05/13/03 & F & 62 & 3.3 & B & 603 & 300 & \\
\hline 71 & $05 / 13 / 03$ & $\mathrm{~F}$ & 73.5 & 5.9 & B & 725 & 28 & \\
\hline 72 & $07 / 17 / 03$ & $\mathrm{~F}$ & nd & 4.4 & B & 1302 & 123 & \\
\hline 73 & $12 / 12 / 01$ & $\mathrm{~F}$ & 62 & 3.2 & B & 6 & 86 & \\
\hline
\end{tabular}

habitat in the tailrace, it was also possible to determine the extent to which fish from both sites were entrained in the tailrace and unable to pass this barrier. Fish were collected with either cast nets or rod and reel with artificial lures. Once captured, fish were visually examined, and only those with no apparent signs of disease, external parasites, or injury were tagged.

Fish were individually anesthetized in an induction bath of clove oil (eugenol) diluted in river water $(1 \mathrm{ml}$ eugenol in $40 \mathrm{l}$ water) for a period of 1 to $3 \mathrm{~min}$. Because little is known about how tropical fish respond to anesthesia, we determined this concentration during preliminary trials. Before tagging, fish were measured (total length to nearest $\mathrm{cm}$ ), weighed (to the nearest $10 \mathrm{~g}$ ), and when possible, sex and reproductive state were determined through external morphological characters (i.e. males have spines on the anal fin during the spawning season). Fish were placed in a surgical holding tray in a supine position such that the gills were continuously irrigated with a maintenance bath of anesthetic solution ( $0.25 \mathrm{ml}$ eugenol in $40 \mathrm{l}$ water) through a tube placed under the operculum. The surgical equipment was disinfected with germicide solution (quaternary ammonium compounds) prepared freshly for each tagging session. An incision of approximately 3 to $4 \mathrm{~cm}$ was made just anterior to the pelvic fin girdle. The incision was deep enough to reach the coelomic cavity. A catheter was inserted through the incision, between the pelvic fin girdle and the viscera, and directed 5 to $10 \mathrm{~mm}$ from the center of the ventral line to serve as an exit site for the antenna. The tag was then inserted through the main incision, gently pulling the free end of the antenna and the catheter and leaving the tag positioned in the coelom. The incision was closed with 4 or 5 absorbable simple interrupted sutures (Vicryl, J\&J Ethicon). Surgeries were conducted by the same trained individual, and procedures were developed in consultation with veterinarians. After surgery, fish were kept in the river in rock holding pools and monitored until the opercula and swimming movements were deemed normal, at which point fish were released.

All tagged dorados (34-97 cm total length, 300$11000 \mathrm{~g}$, see Table 1) recovered from surgical procedures and showed normal opercula and swimming movements when released, typically within 5 min 
after surgery. In this study, the majority $(95 \%)$ of tagged fish had tag to fish body mass ratios that were $1 \%$ or less. For 3 specimens, the tag weight to fish weight ratios were greater $(1.86,2.6$, and $8.67 \%)$ but only the individual with the largest tag burden $(8.67 \%)$ was not tracked after release.

\section{Telemetry equipment and tracking}

Fish were tagged with 3 models of radio transmitters: MCFT-3L $(16 \times 73 \mathrm{~mm}, 26 \mathrm{~g}$ in air, operational life of $812 \mathrm{~d}$ at a $2.5 \mathrm{~s}$ burst rate), MCFT-3CM $(11 \times$ $36 \mathrm{~mm}, 6.7 \mathrm{~g}$ in air, operational life of $150 \mathrm{~d}$ at a $5 \mathrm{~s}$ burst rate), and MCFT-3A (16 × $46 \mathrm{~mm}, 16 \mathrm{~g}$ in air, operational life of $680 \mathrm{~d}$ at a $5 \mathrm{~s}$ burst rate; all tags were from Lotek Wireless). The radio transmitters operated at frequencies between 149.380 and $149.840 \mathrm{MHz}$, separated by at least $20 \mathrm{khz}$. The different tag sizes were used such that we could match tag size to animal size and also reflected changes in product availability during the study period.

Seven radio telemetry fixed stations monitored the movement of tagged fish (F1 downstream to F7 upstream; Fig. 1). Stn F1 was installed after the removal of Stn F5. Each station was equipped with an SRX-400 W7 radio receiver (Lotek Wireless), 4-element Yagi antenna (1 to 3 per station; AV Antronics), cables, and connectors. To power the receiver, electricity from standard wall outlets, batteries, and/or solar panels was used depending on site characteristics. At Stns F6, F5, F4, and F3, antennas were pointed upstream, downstream, and to tributaries. The data stored by each receiver were downloaded to a laptop using proprietary software provided by the receiver manufacturer. Given that this study represented the first large-scale Neotropical riverine telemetry study, several challenges were encountered with respect to tracking fish (see 'Discussion' for more details). For example, several stations suffered interruptions in monitoring due to power failure or vandalism (details regarding fixed station performance are presented in Table 2).

In addition to data obtained from fixed stations, 10 aerial surveys using a small airplane and each lasting $\sim 4 \mathrm{~h}$ were conducted using a radio telemetry receiver (SRX-400 W5) and ' $\mathrm{H}$ ' antenna. Flights (9 in total) were conducted at 200 to $400 \mathrm{~m}$ above water between December 2001 and July 2003 and were restricted to the $400 \mathrm{~km}$ study reach. When a signal was picked up, the position of the fish was recorded with a GPS. For this study, all tagging occurred between November 2001 and July 2003, and the aer- ial and fixed tracking occurred between November 2001 and April 2004. Mobile tracking by road was not possible due to the vast size of the study area and the lack of road access.

\section{Data analysis}

Data files were downloaded from the receivers and imported into Telemetry Manager database software (Version 3.0, LGL Environmental Research Associates). The software sorted all signals and created a new operational database of all signals picked up from the tagged fish, eliminating signals from background noise and erroneous records. The software was used to generate the time of arrival and departure from every receiver zone as well as the number of valid signals recorded for a given time period. For the purpose of the analysis, the study area consisted of 7 fixed tracking zones (F1 to F7) and 12 mobile tracking zones (M1 to M12; Fig. 1). Although we had large sample sizes, a number of problems with the fixed stations reduced the resolution of the data. As such, for the purpose of this study we present summary statistics and general movement trends but do not conduct a rigorous statistical analysis. However, we did examine the relationship between discharge $\left(\mathrm{m}^{3} \mathrm{~s}^{-1}\right)$ from the Itá Dam between November 2001 and April 2004 and the abundance of tagged fish. In some respects, this study represents a natural history account of dorado movement, and this is part of a growing trend in which new technologies are enabling the collection of observational and descriptive data that were previously unattainable (Sagarin \& Pauchard 2010).

\section{RESULTS}

Of the 42 dorados tagged and released at the most downstream site (i.e. tagging Site A, Turvo Forest Park), 17 (40.5\%) were never recorded. Of the 25 fish detected at least once after release, $10(40 \%)$ were recorded at Stn F7 (325 km upstream) between 6 and $769 \mathrm{~d}$ after release. For example, Fishes 1, 2, and 3 were released on 28 November 2001 and were recorded at the most upstream fixed station at Itá Dam on 11 and 12 January 2002. Interestingly, the last 2 were first detected at this station just $7 \mathrm{~h}$ apart, emphasizing the synchronicity of movements (Fig. 2). Upstream migration rates were high for some fish, such as Fish 8, which moved upstream at an average speed of $54.1 \mathrm{~km} \mathrm{~d}^{-1}$. 
Table 2. Summary of fixed station characteristics and performance during the study period. Rkm: river kilometer

\begin{tabular}{|c|c|c|c|c|c|}
\hline $\begin{array}{l}\text { Station/ } \\
\text { name }\end{array}$ & Position & $\begin{array}{l}\text { Rkm to study } \\
\text { area/distance } \\
\text { from mouth }(\mathrm{km})\end{array}$ & Description & $\begin{array}{l}\text { Station } \\
\text { operation } \\
\text { period }\end{array}$ & Comments \\
\hline $\begin{array}{l}\text { F1/Porto } \\
\text { Soberbo }\end{array}$ & $\begin{array}{l}27.30^{\circ} \mathrm{S} \\
54.19^{\circ} \mathrm{W}\end{array}$ & $378 / 1072$ & $\begin{array}{l}250 \mathrm{~m} \text { wide, up to } 71 \mathrm{~m} \text { deep, } \\
2 \text { aerial antennas (pointed } \\
\text { upstream and downstream) }\end{array}$ & $\begin{array}{l}\text { March } 2003 \\
\text { to July } 2004\end{array}$ & $\begin{array}{l}\text { Functioned throughout } \\
\text { the entire study period }\end{array}$ \\
\hline $\begin{array}{l}\text { F2/ } \\
\text { Turvo }\end{array}$ & $\begin{array}{l}27.22^{\circ} \mathrm{S} \\
54.01^{\circ} \mathrm{W}\end{array}$ & $325 / 1125$ & $\begin{array}{l}350 \mathrm{~m} \text {, up to } 18 \mathrm{~m} \text { deep, } 2 \\
\text { aerial antennas (pointed } \\
\text { upstream and downstream) }\end{array}$ & $\begin{array}{l}\text { November } 2001 \\
\text { to July } 2002\end{array}$ & $\begin{array}{l}\text { Problems mainly related } \\
\text { to energy supply; removed } \\
\text { in December } 2002\end{array}$ \\
\hline $\begin{array}{l}\text { F3/ } \\
\text { Itapiranga }\end{array}$ & $\begin{array}{l}27.17^{\circ} \mathrm{S} \\
53.83^{\circ} \mathrm{W}\end{array}$ & $286 / 1164$ & $\begin{array}{l}600 \mathrm{~m} \text {, up to } 5 \mathrm{~m} \text { deep, } \\
3 \text { aerial antennas (pointed } \\
\text { upstream, downstream, and } \\
\text { to tributary) }\end{array}$ & $\begin{array}{l}\text { December } 2001 \\
\text { to July } 2002 ; \\
\text { January to } \\
\text { March } 2003\end{array}$ & $\begin{array}{l}\text { Energy supply problems } \\
\text { from August to December } \\
2002 \text {; receiver stolen in } \\
\text { April } 2003\end{array}$ \\
\hline $\begin{array}{l}\text { F4/ } \\
\text { Mondaí }\end{array}$ & $\begin{array}{l}27.09^{\circ} \mathrm{S} \\
53.38^{\circ} \mathrm{W}\end{array}$ & $212 / 1238$ & $\begin{array}{l}590 \mathrm{~m} \text {, up to } 40 \mathrm{~m} \text { deep, } \\
3 \text { aerial antennas (pointed } \\
\text { upstream, downstream, } \\
\text { and to tributary) }\end{array}$ & $\begin{array}{l}\text { November } 2001 \\
\text { to September } \\
\text { 2003; March } 2004 \\
\text { to July } 2004\end{array}$ & $\begin{array}{l}\text { Receiver damaged by } \\
\text { lightning in September } \\
2003\end{array}$ \\
\hline $\begin{array}{l}\text { F5/Foz do } \\
\text { Chapecó }\end{array}$ & $\begin{array}{l}27.10^{\circ} \mathrm{S} \\
53.01^{\circ} \mathrm{W}\end{array}$ & 132/1318 & $\begin{array}{l}570 \mathrm{~m} \text {, up to } 18 \mathrm{~m} \text { deep, } \\
3 \text { aerial antennas (pointed } \\
\text { upstream, downstream, and } \\
\text { to tributary) }\end{array}$ & $\begin{array}{l}\text { November } 2001 \\
\text { to December } \\
2002\end{array}$ & $\begin{array}{l}\text { Energy supply and } \\
\text { vandalism problems; } \\
\text { removed in } \\
\text { December } 2002\end{array}$ \\
\hline $\begin{array}{l}\text { F6/ } \\
\text { Goio-En }\end{array}$ & $\begin{array}{l}27.29^{\circ} \mathrm{S} \\
52.69^{\circ} \mathrm{W}\end{array}$ & $55 / 1395$ & $\begin{array}{l}250 \mathrm{~m} \text { width, up to } 8 \mathrm{~m} \text { deep, } \\
3 \text { aerial antennas (pointed } \\
\text { upstream, downstream, and } \\
\text { to tributary) }\end{array}$ & $\begin{array}{l}\text { November } 2001 \\
\text { to December } \\
\text { 2002; March } 2003 \\
\text { to March } 2004\end{array}$ & $\begin{array}{l}73 \mathrm{~d} \text { off to send receiver } \\
\text { to Canada to replace } \\
\text { internal battery and } \\
\text { vandalism problems }\end{array}$ \\
\hline $\begin{array}{l}\text { F7/Itá } \\
\text { tailrace }\end{array}$ & $\begin{array}{l}27.28^{\circ} \mathrm{S} \\
52.39^{\circ} \mathrm{W}\end{array}$ & $0 / 1450$ & $\begin{array}{l}190 \mathrm{~m} \text { width, up to } 16 \mathrm{~m} \\
\text { deep, } 1 \text { aerial antenna } \\
\text { pointed downstream }\end{array}$ & $\begin{array}{l}\text { November } 2001 \\
\text { to March } 2004\end{array}$ & $\begin{array}{l}\text { Functioned throughout } \\
\text { the entire study period }\end{array}$ \\
\hline
\end{tabular}

Of the 31 dorados tagged and released at the most upstream site in the tailwaters of Itá Dam (i.e. tagging Site B), 6 resided in the tailwater area throughout the study period. The remaining 25 individuals stayed within $20 \mathrm{~km}$ of the tagging site for between 26 and $781 \mathrm{~d}$ (average $157 \mathrm{~d}$ ). During the course of the study, 8 of those fish moved downstream up to $331 \mathrm{~km}$ and then eventually returned to Itá Dam from 300 to 832 d after release. An additional 17 fish moved downstream from the Itá tagging site and did not return during the study period. The distance of downstream displacements varied between 10 and $400 \mathrm{~km}$ (average of $196 \mathrm{~km}$ ), with downstream displacement speeds ranging between 0.06 and $5.91 \mathrm{~km}$ $\mathrm{d}^{-1}$ (average of $1.67 \mathrm{~km} \mathrm{~d}^{-1}$ ).

Only 2 dorados (1 male and 1 female) caught and tagged at Itá Dam (tagging Site B) on 28 March 2002 were in advanced gonadal maturity stage (ripe gonads; see Table 1). The male (Fish 58), which was releasing sperm during the tagging, stayed on site for $124 \mathrm{~d}$, and was detected later (166 d after release), $70 \mathrm{~km}$ downstream. The female (Fish 61) moved downstream $230 \mathrm{~km}$ after release but was then detected again at the release site 272 d later, where it remained for $155 \mathrm{~d}$ (Fig. 2).

There was a general seasonal tendency of fish released at the downstream Turvo Forest Park (tagging
Site A) to move upstream in November, whereas fish released at the upstream limit of the study site (i.e. Itá Dam, tagging Site B) tended to move downstream beginning in February. Of the fish released at Site A, 17 $(68 \%)$ that migrated at least $100 \mathrm{~km}$ upstream did so between October and March, although upstream movements by fewer fish were also noted between April and September. Of the 10 fish tagged and released at Site A that migrated upstream all the way to Itá Dam (Site B), 2 exhibited repeat migrations in subsequent years, although one of the fish did so after failing to migrate upstream in one year (i.e. migrated in 2001 and 2003 but not in 2002).

The mean abundance of tagged fish in the tailrace of Itá Dam was inversely related to water discharge of the power plant (Fig. 3). However, under low flow conditions (monthly average $<370 \mathrm{~m}^{3} \mathrm{~s}^{-1}$ ), there was high variability in the presence of fish. On the other hand, in very high water discharges $\left(>1400 \mathrm{~m}^{3} \mathrm{~s}^{-1}\right)$, only a few individuals remained in the area (1-3, $\pm 1.71)$.

Eleven radio transmitters $(15 \%$ of the total implanted) were returned to the project by recreational and artisanal fishers both within and downstream of the study site, including 1 fish (Fish 20) that was recaptured $300 \mathrm{~km}$ downstream of the most downstream extent of the study site, 27 mo after tagging. 

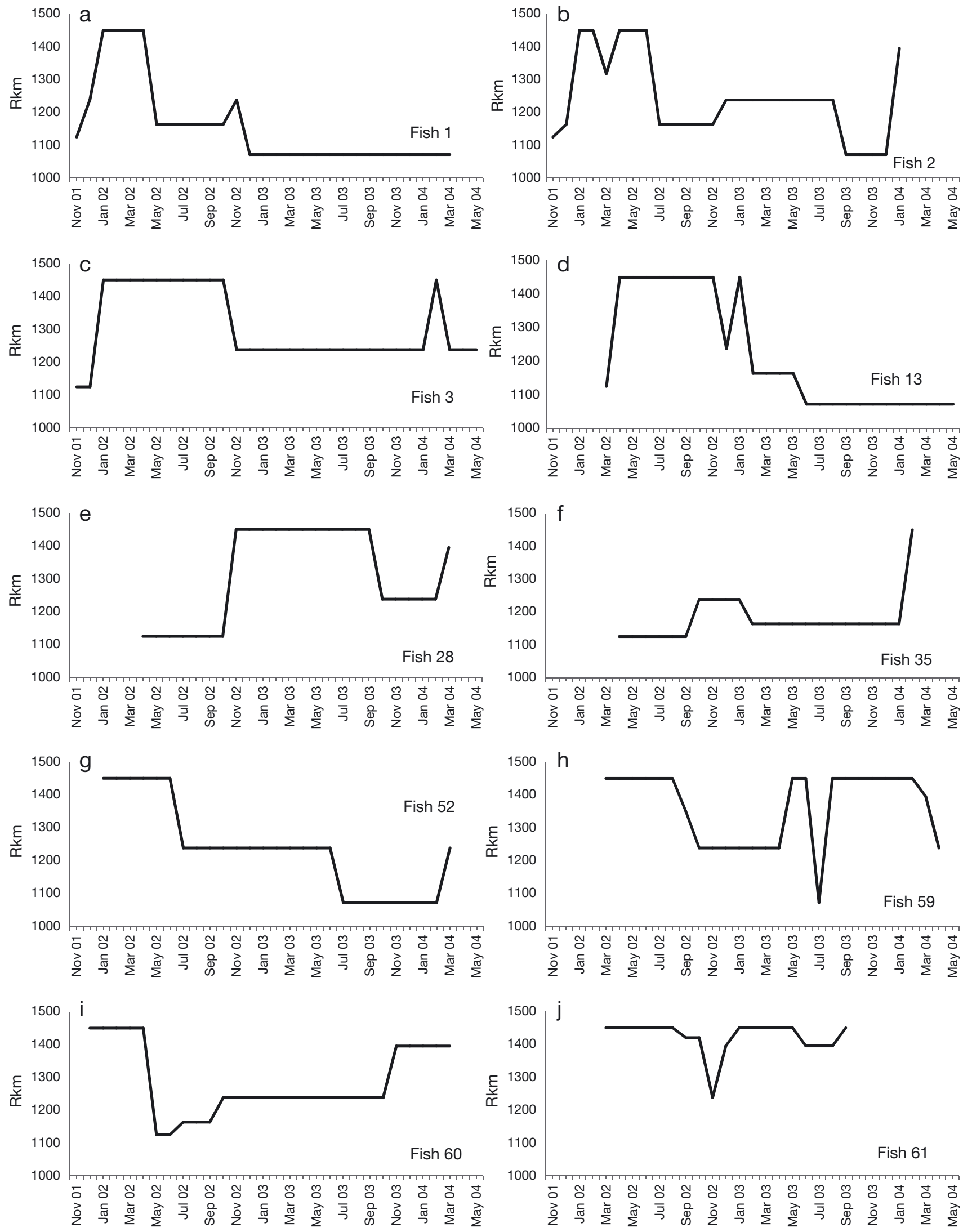

Date (mo/yr) recorded 
Fig. 2. Salminus brasiliensis. Movements of dorados released $(\mathrm{a}-\mathrm{f})$ in the Turvo Forest Park (Site A, $1125 \mathrm{~km}$ from the mouth) and $(\mathrm{g}-\mathrm{j})$ in the tailrace of Itá Dam (Site B, $1450 \mathrm{~km}$ from the mouth. Lines indicate the first and last dates that a fish was detected at a fixed-station receiver prior to detection at another receiver. The fish could have migrated substantial distances away from the receiver site during this interval without being detected). Rkm: distance of the river in $\mathrm{km}$ from the mouth

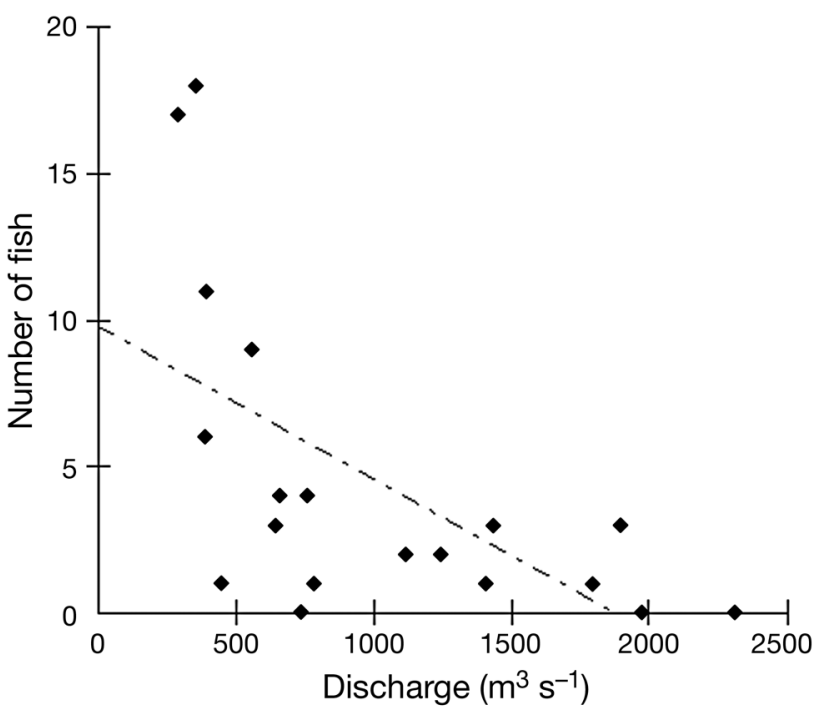

Fig. 3. Salminus brasiliensis. Water discharge from Itá power plant and number of dorado individuals recorded at the tailrace between November 2001 and April 2004

\section{DISCUSSION}

\section{Migratory biology of dorados}

The migratory behavior of dorados is conspicuous and has been described by many authors (Bonetto \& Pignalberi 1964, Bonetto et al. 1971, Petrere 1985, Sverlij \& Espinach-Ros 1986). However, previous studies have relied solely on data generated from mark-recapture studies and thus lack the temporal or spatial resolution presented here. In the current study, we recorded displacements up to $400 \mathrm{~km}$. In an earlier mark-recapture study, Sverlij \& EspinachRos (1986) documented maximal movements up to $1440 \mathrm{~km}$ between the La Plara River estuary and Posadas, Argentina. Two factors likely contributed to our failure to detect larger movements. First, the Itá Dam served as an upstream impassable barrier where many fish accumulated. Second, due to budgetary constraints, our telemetry array and aerial tracking was limited to a $400 \mathrm{~km}$ study reach. Many fish were only detected on a few occasions and were last detected at the most downstream fixed station (Table 1), supporting the idea that some fish were using larger reaches of the river. The maximum speed detected in this study was $63.3 \mathrm{~km} \mathrm{~d}^{-1}$, the largest recorded for the species to date. For comparative purposes, upriver migration speeds of between 20 to $30 \mathrm{~km} \mathrm{~d}^{-1}$ are typically observed for adult Pacific salmon in large rivers in the Pacific Northwest of the USA (e.g. Hanson et al. 2008). Studies carried out in the Paraná River using mark-recapture revealed downstream movements for dorados of up to $1000 \mathrm{~km}$ and upstream up to $250 \mathrm{~km}$ and velocities between 0.4 and $21.5 \mathrm{~km} \mathrm{~d}^{-1}$ (Bonetto \& Pignalberi 1964, Bonetto et al. 1971, Petrere 1985). On the other hand, in the lower Uruguay River, the distance traveled was up to $850 \mathrm{~km}$ to upstream sites and the velocities varied from 3.4 to $21.1 \mathrm{~km} \mathrm{~d}^{-1}$ (Delfino \& Baigún 1985). The velocity of migration is associated with direction, flow characteristics, river hydrology, and the anatomical characteristics and physiological capacity of the species. Nonetheless, the velocities recorded for upstream migration during the spawning period are higher than the downstream migration for feeding, despite fish having to swim against the flow.

Most of the fish released at Turvo Forest Park $(68 \%)$ moved upstream between October and March. The initiation of the spawning season in the upper Uruguay River is strongly related to the rain periods and increases in water temperature, which usually start in September. In the Paraná River Basin, reproduction occurs for dorados between November and January (Barbieri et al. 2001). Reproductive and spawning movements are regulated by rain. If rain and flooding are delayed, migratory species may delay or forego reproduction (Agostinho et al. 2003).

The fish tagged in this study presented different degrees of residency in the study reach. The 17 dorados released at Turvo Forest Park that were never recorded may have moved out of the study area, as corroborated by the capture of a fish downstream of the park, whose tag was returned by fishers. The movement to downstream areas after tagging could be a result of stress caused by handling and tagging (Mäkinen et al. 2000, Thorstad et al. 2001) or it may simply be that these fish inhabit a large home range that extends downstream from the tagging site. The fact that these fish were not detected by any receivers or tracking sessions could be due to 3 primary reasons: (1) problems in the fixed stations or in mobile tracking, (2) fish were captured by fishers and not reported, or (3) transmitter failure. According to 
Winter (2000), the losses from harvesting by humans are often much higher than $30 \%$, and the transmitter failure rate can approach $10 \%$.

Of the dorados released in Turvo Forest Park, $40 \%$ moved upstream to Itá, where they remained for different lengths of time in the tailrace area. The presence of fish for long periods in the Itá Dam tailrace may indicate that the spawning area of this population was previously located upstream of the dam. Further, the water discharge may serve as an attractant for these rheotactic fish; this may be due to the flow itself or to the presence of forage species that reside in the tailrace because of plankton entrainment from the reservoir. However, despite the long-term residency, the relation between water discharge from the Itá power plant and fish concentration at the tailrace was inversely proportional, and may be related to low tolerance of fish to elevated discharges that require fish to make longitudinal or lateral movements to find adequate flow refuge (Lucas \& Baras 2001).

The dam has several large lights which may attract insects or fish, as has been previously proposed as a mechanism for the concentration of fish in the tailrace (Agostinho et al. 1993, 2007). It is most likely that a number of factors influence long-term residency in the tailrace by some of the tagged dorados, such as the lack of suitable spawning habitat in the tributaries downstream of the Itá Dam. The return of 2 dorados released at Turvo Forest Park to Itá on 2 occasions may suggest fidelity to spawning grounds, which were probably historically located upstream of the dam. These fish returned to Itá after taking a year's break, suggesting that they may not attempt reproduction annually or that some individuals do not need to migrate to reproduce; however this is still poorly understood. In the upper Paraná River, parts of the tagged schools of Salminus brasiliensis and Prochilodus lineatus remained at the release site for long periods, which suggests that these species may complete their life cycles without migrating (Agostinho et al. 2003).

\section{Comments on the use of biotelemetry in Neotropical rivers}

Radio telemetry is an appropriate technology to collect qualitative and quantitative information about fish movements and habitat utilization, especially in remote places and turbid waters (Eiler et al. 1991, Thorstad et al. 2001). However, collection and analysis of data in this study were especially challenging for several reasons. For example, many areas of the study reach were $>3 \mathrm{~m}$ deep with widths exceeding $400 \mathrm{~m}$, making it difficult to detect and decode radio signals. Indeed, many tagged fish passed by more than 2 fixed stations without being detected, which emphasizes our poor detection efficiency. In addition, there was extensive but inconsistent background noise which may have further reduced the ability of the receiver to record valid signals. The receiver stations also became infested with insects and affected by moisture. It is thus important to design fixed stations that keep animals and moisture out, as these can both influence receiver performance. Finally, aerial surveys were largely ineffective due to the fact that the plane had to fly at between 200 and $400 \mathrm{~m}$ above the water, a height that was higher than most previous aerial tracking studies (Holder \& Eiler 2000). The lack of roads along vast reaches of the study site made manual tracking by truck difficult, and treacherous rapids in some areas made tracking by boat quite dangerous. Several fixed stations were vandalized during the study period, and one was stolen, which was not only expensive but also meant a loss of data. In addition, when the receivers required technical service, they had to be sent to Canada, and with customs and shipping challenges, this sometimes took several months. In other words, there is simply no capacity for technical support for telemetry equipment in Neotropical regions. From a biological perspective, it was necessary to develop tagging protocols for a species that had previously not been anesthetized or implanted with electronic tags. In the case of this study, there was not even an appropriate surrogate species that had previously been studied in the literature (see Ebner et al. 2009), so we had to rely on accounts from researchers tagging large riverine fish in other areas (e.g. salmonids in North America). Although not ideal, this approach seemed to work for our study but should not become standard practice for future studies in Neotropical regions.

To overcome the challenges that we faced here, we provide a number of recommendations for those interested in pursuing telemetry studies in Neotropical systems in the future. First and foremost, it is important to consider what type of technology should be used, given that fixed acoustic telemetry stations are also becoming popular in large-river research (e.g. Mathes et al. 2010). At the time of this study, radio telemetry was certainly the best option, but today there are a number of options that should be considered (e.g. acoustic telemetry). It is also important to conduct range tests to optimize receiver performance and identify problems with detection efficiency that could be addressed using amplifiers, different antennas, or alternate antenna configura- 
tions. Ideally, such tests would be done at the project planning phase to determine the number of systems required, their location, and their specifications. To avoid vandalism and theft, it is important to be cryptic with receiver placement or place gear in areas where it is secure (e.g. private land with landowner permission). Furthermore, if telemetry companies are to serve Neotropical and other regions outside of North America and Europe more effectively, it is necessary to have local technical support to service telemetry gear. In terms of tag attachment and implantation, there is certainly a need for studies of tagging effects, development of anesthesia protocols, and testing of surgical procedures on a range of Neotropical fish species. Collectively, these recommendations should be useful for researchers that are considering the use of biotelemetry techniques for the study of fish in Neotropical rivers.

\section{Management and conservation implications}

The study revealed important information about the timing and speed of dorado movements. Given that there appears to be a large concentration of fish in the tailrace region of Itá Dam during the spawning period, there are several management and conservation implications. One option may be to install a fish passage device to enable fish to bypass the dam. This option assumes that if dorados had access to upstream areas, there would indeed be suitable spawning habitat despite the presence of the reservoir and other dams. As such, a fishway could create an 'ecological trap,' a phenomenon documented for other large migratory fish in Brazil (Pelicice \& Agostinho 2008). In addition, little is known about the behavior of dorados in or near fishways or their swimming abilities, so biological design criteria are lacking. Clearly, there is a need to transplant some fish above the Itá Dam and use telemetry to identify potential spawning areas. Another option is to create spawning habitat downstream of the dam to increase production of dorados. Between Itá and Machadinho Dams there is a tributary (Ligeiro River) which may provide suitable spawning habitats for migratory species, although future biotelemetry studies are needed to determine whether this is the case. Finerscale habitat use studies with a greater emphasis on manual tracking may be useful for identifying critical habitats. In this study, we focused on documenting large-scale movements.

In summary, our data suggest that large segments of the population of dorados in the $400 \mathrm{~km}$ reach of the Uruguay River downstream from Itá Dam make upstream spawning migrations that terminate in the vicinity of Itá Dam where there is limited or potentially no spawning habitat. Without efforts to improve the productive capacity of the system and provide fish with access to suitable spawning sites, the population of dorados in the Uruguay River may face further declines and eventual extirpation. This should also serve as a lesson for future dam developments on other Neotropical rivers where dorados occur. However, it is also likely that this scenario is relevant to many other Neotropical migratory fish that have not been studied. As noted above, this is one of the first radio telemetry studies on fish in Neotropical rivers. Telemetry data are essential for providing information to inform both threat assessments and to identify potential conservation and management actions (Cooke 2008), and additional efforts are needed to build the capacity for such studies in Neotropical regions and other areas where biotelemetry has yet to be fully embraced but has much to offer conservation biologists (Hocutt et al. 1994).

Acknowledgements. We thank the World Fisheries Trust and staff of the LGL Environmental Research Associates for their valuable assistance in training and data analysis. Tractebel Energia provided financial support for this study. J. L. L. Pereira kindly provided the map of the Uruguay River. We also thank people from Nupelia (Center for Research in Limnology, Ichthyology and Aquaculture) for their support in data analysis, comments, and suggestions on the manuscript, especially F. Abujanra. The Brazilian government agencies CNPq and CAPES provided scholarship support for L.H. This study was part of the $\mathrm{PhD}$ dissertation of L.H. at the State University of Maringá, Paraná, Brazil.

\section{LITERATURE CITED}

Agostinho AA, Mendes VP, Suzuki HI, Canzi C (1993). Avaliação da atividade reprodutiva da comunidade de peixes dos primeiros quilômetros a jusante do reservatório de Itaipu. Rev UNIMAR 15(Suppl):175-189

Agostinho AA, Gomes LC, Fernandez DR, Suzuki HI (2002) Efficiency of fish ladders for Neotropical ichthyofauna. River Res Appl 18:299-306

Agostinho AA, Gomes LC, Suzuki HI, Júlio HF Jr (2003) Migratory fishes of the upper Paraná River Basin, Brazil. In: Carosfeld J, Harvey B, Ross C, Baer A (eds) Migratory fishes of South America: biology, fisheries and conservation status. World Fisheries Trust/World Bank/IDRC, Victoria, p 19-98

Agostinho CS, Pereira CR, Oliveira RJ, Freitas IS, Marques EE (2007) Movements through a fish ladder: temporal patterns and motivations to move upstream. Neotrop Ichthyol 5:161-167

Baras E (1991) A bibliography on underwater telemetry, 1956-1990. Can Tech Rep Fish Aquat Sci 1819:1-55

Barbieri G, Salles FA, Cestarolli MA (2001) Reproductive 
and nutritional dynamics of Salminus maxillosus Valenciennes, 1849 (Pisces, Characidae) at Mogi Guaçu river, state of São Paulo, Brazil. Acta Sci 23:441-444

Bonetto AA, Pignalberi C (1964) Nuevos aportes al conocimiento de las migraciones de los peces en los ríos mesopotámicos de la República Argentina. Comun Inst Nac Limnol St Tomé 1:1-14

Bonetto AA, Pignalberi C, Cordibiola de Yuan E, Oliveros O (1971) Informaciones complementarias sobre migraciones de peces em la cuenca de La Plata. Physis 30: 505-520

Carosfeld J, Harvey B (2003) Fishes of the floods. In: Carosfeld J, Harvey B, Ross C, Baer A (eds) Migratory fishes of South America: biology, fisheries and conservation status. World Fisheries Trust/World Bank/IDRC, Victoria, p 5-18

> Cooke SJ (2008) Biotelemetry and biologging in endangered species research and animal conservation: relevance to regional, national, and IUCN Red List threat assessments. Endang Species Res 4:165-185

Delfino R, Baigún C (1985) Marcaciones de peces en el embalse de Salto Grande, Rio Uruguay (ArgentinaUruguay). Rev Assoc Cienc Nat Litor 16:85-93

Di Persia DH, Neiff JJ (1986) The Uruguay River system. In: Davies BR, Walker W (eds) The ecology of river systems. Dr. W. Junk Publishers, Dordrecht, p 599-621

Ebner B, Lintermans M, Jekabsons M, Dunford M, Andrews W (2009) A cautionary tale: surrogates for radio-tagging practice do not always simulate the responses of closely related species. Mar Freshw Res 60:371-378

Eiler JH, Nelson BD, Bradshaw RF (1991) Radio tracking chinook salmon (Oncorhynchus tshawytscha) in a large turbid river. In: Uchiyama A, Amlaner C Jr (eds) Proc 11th Int Symp Biotelemetry, Yokohama, Japan. Waseda University Press, Tokyo, p 202-206

Godoy MP (1975) Peixes do Brasil, subordem Characoidei. Bacia do rio Mogi Guassu. Piracicaba, Brasil. Editora Franciscana, São Paulo

Hahn L (2000) Diversidade, composição da ictiofauna e aspectos da biologia de Salminus maxillosus e Prochilodus lineatus do rio Uruguai superior, entre Mondai e Itapiranga, Santa Catarina, Brasil. MSc thesis, Pontifícia Universidade Católica do Rio Grande do Sul, Porto Alegre

Hahn L, Câmara LF (2000) Ictiofauna do rio Uruguai superior: pesquisas e impactos. Bol Soc Bras Ictiol 58:9-11

Hanson KC, Cooke SJ, Hinch SG, Crossin GT and others (2008) Individual variation in migration speed of upriver migrating sockeye salmon in the Fraser River in relation to their physiological and energetic status at marine approach. Physiol Biochem Zool 81:255-268

Hocutt CH, Seibold SE, Jesien RV (1994) Potential use of biotelemetry in tropical continental waters. Rev Hydrobiol Trop 27:77-95

Holder RR, Eiler JH (2000) Practical aspects of aerial tracking salmon in remote Alaska rivers. In: Eiler JH, Alcorn DJ, Neuman MR (eds) Proc 15th Int Symp Biotelemetry, Juneau, AK. International Society on Biotelemetry, Wageningen, p 154-160

Lowe-McConnell R (1975) Fish communities in tropical freshwaters: their distribution, ecology and evolution. Longman Press, London

Lucas MC, Baras E (2000) Methods for studying spatial behaviour of freshwater fishes in the natural environ- ment. Fish Fish 1:283-316

Lucas MC, Baras E (2001) Migration of freshwater fish. Blackwell Scientific, Oxford

Mäkinen TS, Niemelä E, Moen K, Lindström R (2000) Behaviour of gill-net and rod-captured Atlantic salmon (Salmo salar L.) during upstream migration and following radio tagging. Fish Res 45:117-127

Malmqvist B, Rundle S (2002) Threats to the running water ecosystems of the world. Environ Conserv 29:134-153

Marques AAB, Fontana CS, Vélez E, Bencke GA, Schneider M, Reis RE (eds) (2002) Lista das espécies da fauna ameaçadas de extinção no Rio Grande do Sul. Decreto n. 41.672, de 11 de junho de 2002. FZB/MCTPUCRS/PANGEA. Publicações Avulsas FZB, 11, Porto Alegre

Mathes MT, Hinch SG, Cooke SJ, Crossin GT, Patterson DA, Lotto AG, Farrell AP (2010) Effect of water temperature, timing, physiological condition and lake thermal refugia on migrating adult Weaver Creek sockeye salmon (Oncorhynchus nerka). Can J Fish Aquat Sci 67:70-84

Morais-Filho MB, Schubart O (1955) Contribuição ao estudo do dorado (Salminus maxillosus Val.) do Rio Mogi Guassu (Pisces, Characidae). Ministério da Agricultura, Divisão de Caça e Pesca, São Paulo

Nilsson C, Reidy CA, Dynesius M, Revenga C (2005) Fragmentation and flow regulation of the world's large river systems. Science 308:405-408

OEA (Organização dos Estados Americanos) (1969) Cuenca del Rio de La Plata. Estudio para su planificacion y desarrollo. Inventario de dados hidrológicos y climáticos. OEA, Washington, DC

Pelicice FM, Agostinho AA (2008) Fish-passage facilities as ecological traps in large Neotropical rivers. Conserv Biol 22:180-188

Pesavento SJ (1982) História do Rio Grande do Sul. Mercado Aberto, Porto Alegre

Petrere M Jr (1985) Migraciones de peces de agua dulce en America Latina: algunos comentarios. COPESCAL Doc Ocas 1:1-17

Pringle C (2000) River conservation in tropical versus temperate latitudes. In: Boon PJ (ed) Global perspectives in river conservation: science, policy and practice. John Wiley \& Sons, Chichester, p 371-384

Sagarin R, Pauchard A (2010) Observational approaches in ecology open new ground in a changing world. Front Ecol Environ 8:379-386

Sverlij SB, Espinach-Ros A (1986) El dorado, Salminus maxillosus (Pisces, Characiformes), en el rio de la Plata y rio Uruguay Inferior. Rev Invest Desarr Pesq 6:57-75

> Thorstad EB, Hay CJ, Næsje TF, Okland F (2001) Movements and habitat utilization of three cichlid species in the Zambezi River, Namibia. Ecol Freshw Fish 10: 238-246

Winter JD (2000) Designing telemetry studies and other technical and analytical considerations. In: Eiler $\mathrm{JH}_{\text {, }}$ Alcorn DJ, Neuman MR (eds) Proc 15th Int Symp Biotelemetry, Juneau, AK. International Society on Biotelemetry, Wageningen, p 229-247

Wishart MJ, Davies BR, Boon PJ, Pringle CM (2000) Global disparities in river conservation: 'First World' values and 'Third World' realities. In: Boon PJ (ed) Global perspectives in river conservation: science, policy and practice. John Wiley \& Sons, Chichester, p 354-369 